\title{
Assessment of Natural Radioactivity Levels and Radiation Hazards in Agricultural and Virgin Soil in the State of Kedah, North of Malaysia
}

\author{
Ghazwa Alzubaidi, ${ }^{1}$ Fauziah B. S. Hamid, ${ }^{2,3}$ and I. Abdul Rahman ${ }^{4}$ \\ ${ }^{1}$ Physics Department, Faculty of Science, University of Malaya, Kuala Lumpur, Malaysia \\ ${ }^{2}$ Institute of Biological Science, Faculty of Science, University of Malaya, Kuala Lumpur, Malaysia \\ ${ }^{3}$ Centre for Research in Waste Management, Faculty of Science, University of Malaya, 50603 Kuala Lumpur, Malaysia \\ ${ }^{4}$ School of Applied Physics, Faculty of Science \& Technology, Universiti Kebangsaan, Selangor, Malaysia
}

Correspondence should be addressed to Ghazwa Alzubaidi; physics8@outlook.com

Received 8 May 2016; Accepted 21 September 2016

Academic Editor: Giuseppe Patanè

Copyright (C) 2016 Ghazwa Alzubaidi et al. This is an open access article distributed under the Creative Commons Attribution License, which permits unrestricted use, distribution, and reproduction in any medium, provided the original work is properly cited.

\begin{abstract}
The activity concentrations of naturally occurring radionuclides ${ }^{226} \mathrm{Ra},{ }^{232} \mathrm{Th}$, and ${ }^{40} \mathrm{~K}$ were determined in 30 agricultural and virgin soil samples randomly collected from Kedah, north of Malaysia, at a fertile soil depth of $0-30 \mathrm{~cm}$. Gamma-ray spectrometry was applied using high-purity germanium (HPGe) gamma-ray detector and a PC-based MCA. The mean radioactivity concentrations of ${ }^{226} \mathrm{Ra},{ }^{232} \mathrm{Th}$, and ${ }^{40} \mathrm{~K}$ were found to be $102.08 \pm 3.96,133.96 \pm 2.92$, and $325.87 \pm 9.83 \mathrm{~Bq} \mathrm{~kg}^{-1}$, respectively, in agricultural soils and $65.24 \pm 2.00,83.39 \pm 2.27$, and $136.98 \pm 9.76 \mathrm{~Bq} \mathrm{~kg}^{-1}$, respectively, in virgin soils. The radioactivity concentrations in agricultural soils are higher than those in virgin soils and compared with those reported in other countries. The mean values of radium equivalent activity $\left(\mathrm{Ra}_{\mathrm{eq}}\right)$, absorbed dose rates $D\left(\mathrm{nGy} \mathrm{h}^{-1}\right)$, annual effective dose equivalent, and external hazard index $\left(H_{\mathrm{ex}}\right)$ are $458.785 \mathrm{~Bq} \mathrm{~kg}^{-1}, 141.62 \mathrm{nGy} \mathrm{h}^{-1}$, and $0.169 \mathrm{mSvy}^{-1}$, respectively, in agricultural soils and $214.293 \mathrm{~Bq} \mathrm{~kg}^{-1}, 87.47 \mathrm{nGy} \mathrm{h}^{-1}$, and $0.106 \mathrm{mSv} \mathrm{y}^{-1}$, respectively, in virgin soils, with average $H_{\mathrm{ex}}$ of 0.525 . Results were discussed and compared with those reported in similar studies and with internationally recommended values.
\end{abstract}

\section{Introduction}

Humans are exposed to natural radioactivity at different levels depending on natural radioactive elements present in each area; as such, researchers investigated the natural environmental radiation and radioactivity in soils to conduct background checks and detect environmental radioactivity [1]. The levels of radioactivity can be used to assess public dose rates and radioactive contamination and predict changes in environmental radioactivity caused by nuclear accidents, industrial activities, and other human activities [2].

Potassium-40, uranium-238, and thorium-232 and their decay products are important natural elements that contribute to a large part of the radiation dose received by humans; thus far, approximately 60 abundantly distributed radionuclides have been identified. Radionuclides are encountered in terrestrial strata (soil or rocks) or lakes and water bodies (ocean, sea, or lakes) and can be easily accumulated into the food chain [3].

Specific levels of terrestrial environmental radiation are related to the geological composition of each lithologically separated area and to the contents of thorium (Th), uranium $(\mathrm{U})$, and potassium $(\mathrm{K})$ in rocks from which soils originate. Soils are categorized into several types depending on their physical and chemical properties. Many studies conducted worldwide showed that ${ }^{238} \mathrm{U}$, including its decay products in soils and rocks, and ${ }^{232} \mathrm{Th}$ in monazite sands are the main sources of high natural background radiation [4].

Natural environmental radiation and radioactivity in soils have gained considerable research interest because humans are exposed to natural radioactivity at different levels depending on natural radioactive minerals present in each region worldwide [1]. 


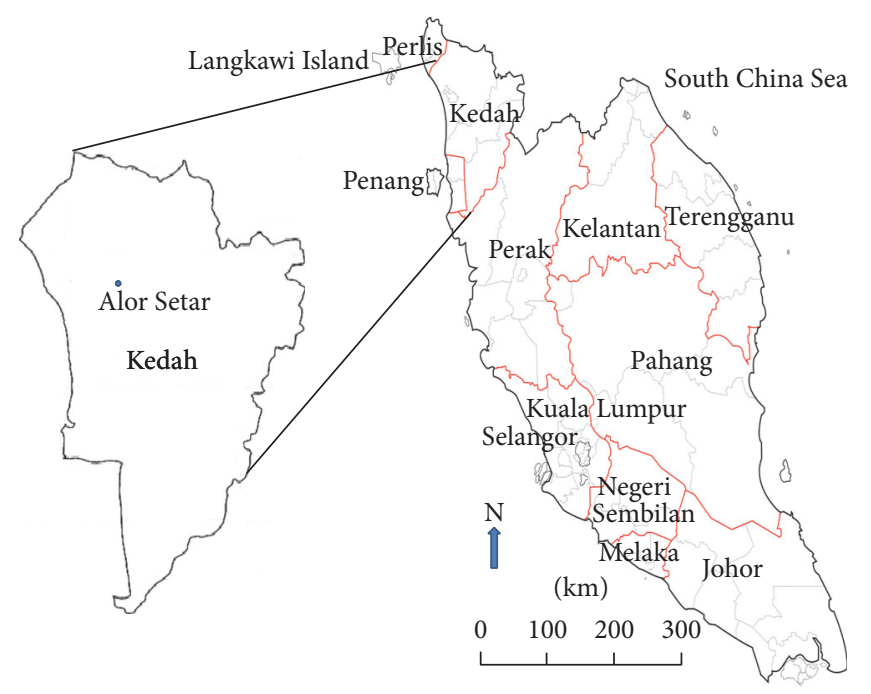

FIGURE 1: Map of the area studied.

Radionuclides in phosphate rocks can enter the environment through different mechanisms, such as use of phosphogypsum for building materials and for agriculture or fertilization of agricultural lands. Direct fallout from the atmosphere on the vegetation is the primary source of radiation contamination. Fission product ${ }^{137} \mathrm{C}$ is strongly absorbed and maintained by soil particles, similar to natural radionuclides, which are widely distributed at different soil depths. Therefore, knowledge on radionuclide distribution in soils is essential to control health risks to the affected population.

In this study, the concentration of radioactivity and the radiation dose from agricultural soils of rice farms and virgin soils in Kedah, Malaysia, were analyzed. Results can be used to determine public dose rates, assess the performance of epidemiological studies, and maintain reference data to ascertain changes in environmental radioactivity caused by nuclear, industrial, and other human activities.

\section{Experimental Procedures}

2.1. Location of Study Area. Surface soil samples were randomly collected from different locations of fertile soil in Kedah in the northwestern part of Peninsular Malaysia $6^{\circ} 7^{\prime} 6.2400^{\prime \prime} \mathrm{N}$ and $100^{\circ} 22^{\prime} 6.4560^{\prime \prime} \mathrm{E}$ (Figure 1) and used to measure natural radioactivity in soil. Kedah covers an area of 9,425 sq. $\mathrm{km}$, and its agriculture industry is largely dedicated to industrial crops. About 518 ha of land in the state is utilized for agriculture, 108 ha is covered by rubber trees, 84 ha is planted with oil palms, and 112 ha is used for cultivating rice. The mainland has a relatively flat terrain and is widely used to grow rice. The average annual rainfall in Kedah ranges from $2032 \mathrm{~mm}$ to $2540 \mathrm{~mm}$.

Vast agricultural areas in the state of Kedah and intensive use of phosphate fertilizers for reclaiming farmland have impelled researchers to investigate the concentration levels of radionuclides in these areas and compare them with those of virgin soil. The levels of radioactivity concentration of radionuclides in agriculture and virgin soil samples provide useful information for monitoring of environmental radiation contamination.

2.2. Samples Collection and Preparation. Thirty samples were collected at a depth of $0-30 \mathrm{~cm}$ from rice farms and virgin soil to measure natural radioactivity. The samples were dried at $100^{\circ} \mathrm{C}$ for $24 \mathrm{~h}$ in an oven and constant dry weights were obtained to determine moisture content [23].

The dried samples were crushed into fine powder by using a soil blender. The powdered samples were sieved through 100-micron mesh to keep uniform grain size and obtain affine-grained homogenous soil samples for measurements [24]. About $500 \mathrm{~g}$ of the homogenous soil sample was packed and sealed in an air-tight Marinelli beaker and stored for 4 weeks before gamma-ray analysis; this incubation period allows ${ }^{226} \mathrm{Ra}$ and its short-lived progenies to achieve secular equilibrium $[25,26]$.

Gamma spectrometry analysis was performed using a gamma-ray spectrometer with a p-type coaxial HPGe $\gamma$-ray spectrometer and a p-type coaxial ORTEC, GEM-25 HPGe gamma-ray detector with $57.5 \mathrm{~mm}$ diameter and $51.5 \mathrm{~mm}$ thick crystals.

The detector was set under the following conditions: operating voltage, $+2800 \mathrm{~V}$; relative efficiency, $28.2 \%$; energy resolution, $1.67 \mathrm{keV}$; and full width at half maximum, $1.33 \mathrm{MeV}$. The detector was coupled with ${ }^{60} \mathrm{C}$ emission and $16 \mathrm{k}$ Multichannel Analyzers for data acquisition. Genie 2000 software from Canberra was used to analyze the spectra. The detector was covered by a cylindrical lead shield with a fixed bottom and a movable cover to reduce the interference of background radiation from terrestrial and extraterrestrial sources in the measured spectrum.

An empty Marinelli beaker was counted in the same way to remove the background radiation from the samples. After the measurement, the background radiation was subtracted 
TABLE 1: Gamma-ray energy and emission rate for ${ }^{238} \mathrm{U},{ }^{232} \mathrm{Th}$, and ${ }^{40} \mathrm{~K}$ radionuclides.

\begin{tabular}{|c|c|c|c|c|c|}
\hline Element & Nuclide & Half-life & Gamma-ray energy $E_{g}(\mathrm{keV})$ & Emission rate & Sources/origin \\
\hline \multirow{3}{*}{${ }^{238} \mathrm{U}$} & ${ }^{214} \mathrm{~Pb}$ & $26.8 \mathrm{~min}$ & 351 & 35.8 & ${ }^{238} \mathrm{U}\left({ }^{226} \mathrm{Ra}\right)$ series \\
\hline & \multirow{2}{*}{${ }^{214} \mathrm{Bi}$} & \multirow{2}{*}{$19.9 \mathrm{~min}$} & 609.3 & 45.4 & \multirow{2}{*}{${ }^{238} \mathrm{U}\left({ }^{226} \mathrm{Ra}\right)$ series } \\
\hline & & & 1764.5 & 15.3 & \\
\hline \multirow{5}{*}{${ }^{232} \mathrm{Th}$} & & \multirow{5}{*}{$6.15 \mathrm{~h}$} & 338.4 & 11.4 & \multirow{5}{*}{${ }^{232}$ Th series } \\
\hline & ${ }^{228} \mathrm{Ac}$ & & 911.1 & 25.8 & \\
\hline & & & 968.9 & 17.4 & \\
\hline & ${ }^{212} \mathrm{~Pb}$ & & 238.63 & 46.6 & \\
\hline & ${ }^{208} \mathrm{Tl}$ & & 583.19 & 85.0 & \\
\hline${ }^{40} \mathrm{~K}$ & ${ }^{40} \mathrm{~K}$ & $1.28 \times 10^{9} \mathrm{yr}$ & 1460.8 & 10.7 & Primordial \\
\hline
\end{tabular}

to determine naturally occurring background distribution in the environment around the detector [6].

Energy calibration and relative efficiency calibration of the spectrometer were performed using Marinelli calibration sources containing the following: ${ }^{210} \mathrm{~Pb} \quad(46.54 \mathrm{keV})$, ${ }^{241} \mathrm{Am}(59.541 \mathrm{keV}),{ }^{109} \mathrm{Cd}(88.040 \mathrm{keV}),{ }^{57} \mathrm{C}(122.061$ and $136.474 \mathrm{keV}),{ }^{123 \mathrm{~m}} \mathrm{Te} \quad(159.00 \mathrm{keV}),{ }^{203} \mathrm{Hg} \quad(279.195 \mathrm{keV})$, ${ }^{113} \mathrm{Sn}(391.698 \mathrm{keV}),{ }^{85} \mathrm{Sr}(514.007 \mathrm{keV}),{ }^{137} \mathrm{Cs}(661.657 \mathrm{keV})$, ${ }^{88} \mathrm{Y}(898.042$ and $1836.063 \mathrm{keV})$, and ${ }^{60} \mathrm{Co}$ (1173.22 and $1332.492 \mathrm{keV})$. The calibration source with an initial activity of $5.109 \mu \mathrm{Ci}$ was obtained from Isotope Products Laboratories (Valencia, CA 91355, USA).

Each sample and background data were counted for 86400 s. Gamma spectroscopy was used to determine the activities of ${ }^{238} \mathrm{U},{ }^{232} \mathrm{Th}$, and ${ }^{40} \mathrm{~K}$.

The specific activity of ${ }^{226} \mathrm{Ra}$ was assessed from gammaray lines of ${ }^{214} \mathrm{~Pb}$ at $351 \mathrm{keV}$ and ${ }^{214} \mathrm{Bi}$ at 609.3 and $1764.5 \mathrm{keV}$, while the specific activity of ${ }^{232}$ Th had been evaluated from gamma-ray lines of ${ }^{228} \mathrm{Ac}$ at $338.4,911.1$, and $968.9 \mathrm{keV},{ }^{212} \mathrm{~Pb}$ at $238.63 \mathrm{keV}$, and ${ }^{208} \mathrm{Tl}$ at $583.19 \mathrm{keV}$. The specific activity of ${ }^{40} \mathrm{~K}$ was directly determined from its gamma-ray line at $1460.8 \mathrm{keV}$ (Table 1).

\section{Results and Discussion}

3.1. The Activity Concentration. Radioactivity concentration was measured using a gamma-ray spectrometer. The radioactivity of natural radionuclides, namely, uranium and thorium series, as well as ${ }^{40} \mathrm{~K}$, was investigated in soil samples collected from Kedah. The primordial radionuclides of ${ }^{226} \mathrm{Ra},{ }^{232} \mathrm{Th}$, and ${ }^{40} \mathrm{~K}$ were the three most important detected in the zone $[27,28]$.

The radioactivity concentrations of these radionuclides were calculated using the following formula [29]:

$$
A=\frac{N}{P \gamma \times \varepsilon \times W}\left(\mathrm{~Bq} \mathrm{~kg}^{-1}\right),
$$

where $A=\left(\mathrm{Bq} \mathrm{kg}^{-1}\right), N$ is net counts per second $(\mathrm{CPS})=$ (sample CPS - background CPS), $P \gamma$ is intensity of the radionuclide, $E$ is efficiency in $\%$, and $W$ is weight of sample in gram.

The activity concentrations in 30 soil samples that were determined using HPGe detector are reported in (Table 2).
The measured activity concentration of ${ }^{226} \mathrm{Ra}$ in agricultural soil samples ranged from $58.93 \pm 1.80 \mathrm{~Bq} \mathrm{~kg}^{-1}$ to $166.55 \pm$ $6.66 \mathrm{~Bq} \mathrm{~kg}^{-1}$, with a mean value of $102.08 \pm 3.96 \mathrm{~Bq} \mathrm{~kg}^{-1}$. The concentration of ${ }^{232}$ Th ranged from $87.98 \pm 1.35 \mathrm{~Bq} \mathrm{~kg}^{-1}$ to $180.45 \pm 3.15 \mathrm{~Bq} \mathrm{~kg}^{-1}$, with an average value of $133.96 \pm$ $2.92 \mathrm{~Bq} \mathrm{~kg}^{-1}$. The activity of ${ }^{40} \mathrm{~K}$ in agricultural soil samples ranged from $202.2 \pm 11.72 \mathrm{~Bq} \mathrm{~kg}^{-1}$ to $529.17 \pm 10.19 \mathrm{~Bq} \mathrm{~kg}^{-1}$, with an average value of $325.87 \pm 9.83 \mathrm{~Bq} \mathrm{~kg}^{-1}$.

The activity concentration of ${ }^{226} \mathrm{Ra}$ in virgin soil samples varied from $45.11 \pm 2.44 \mathrm{~Bq} \mathrm{~kg}^{-1}$ to $111.4 \pm 1.3 \mathrm{~Bq} \mathrm{~kg}^{-1}$, with a mean value of $65.24 \pm 2.00 \mathrm{~Bq} \mathrm{~kg}^{-1}$. The activity concentration of ${ }^{232} \mathrm{Th}$ ranged from $51.83 \pm 1.18 \mathrm{~Bq} \mathrm{~kg}^{-1}$ to $127.35 \pm 6.03 \mathrm{~Bq} \mathrm{~kg}^{-1}$, with an average value of $83.39 \pm$ $2.27 \mathrm{~Bq} \mathrm{~kg}^{-1}$. The concentration of ${ }^{40} \mathrm{~K}$ radionuclides in soil samples ranged from $99.2 \pm 12.1 \mathrm{~Bq} \mathrm{~kg}^{-1}$ to $172.85 \pm$ $7.71 \mathrm{~Bq} \mathrm{~kg}^{-1}$, with an average value of $136.98 \pm 9.76 \mathrm{~Bq} \mathrm{~kg}^{-1}$.

The recommended reference levels of ${ }^{226} \mathrm{Ra},{ }^{232} \mathrm{Th}$, and ${ }^{40} \mathrm{~K}$ are 35,30 , and $400 \mathrm{~Bq} \mathrm{~kg}^{-1}$, respectively, as listed in the world average concentrations published by UNSCEAR (2000). The average concentrations of ${ }^{226} \mathrm{Ra}$ and ${ }^{232} \mathrm{Th}$ obtained in the present study are higher than the recommended reference levels. The mean concentrations of the natural radioactivity of virgin and agricultural soils were also compared with the range and average of the natural radioactivity concentration levels reported in other studies (Table 3). The mean concentrations of ${ }^{226} \mathrm{Ra},{ }^{232} \mathrm{Th}$, and ${ }^{40} \mathrm{~K}$ in virgin and agricultural soils in the present study are higher than those reported by Ahmad et al. [7] and Saleh et al. [6] studies which was carried out by the first researcher to assess the concentration radioactivity levels in agricultural areas of palm oil and bananas of Kedah.

The results were also compared with those reported in studies conducted in other countries (Table 6). The mean activity concentrations of natural radioactivity of ${ }^{226} \mathrm{Ra}$, ${ }^{232} \mathrm{Th}$, and ${ }^{40} \mathrm{~K}$ in agricultural soil samples in the present study are higher than those reported in agricultural soils of India, Pakistan, Algeria, Egypt, Thailand, and Greece. Phosphate fertilizers are extensively applied in the farmlands of rice; therefore, the activity concentration of ${ }^{226} \mathrm{Ra}$ was enhanced in these farmlands. The enhancement in the radioactivity concentration of ${ }^{226} \mathrm{Ra}$ could be attributed to fertilization with phosphate rocks, which contain substantial amounts 
TABLE 2: The activity concentrations of ${ }^{226} \mathrm{Ra},{ }^{232} \mathrm{Th}$, and ${ }^{40} \mathrm{~K}\left(\mathrm{~Bq} \mathrm{~kg}^{-1}\right)$ in agricultural and virgin soil samples collected from Kedah soil of north Malaysia.

\begin{tabular}{|c|c|c|c|c|c|c|c|c|}
\hline \multirow{2}{*}{ Sample number } & \multicolumn{3}{|c|}{ Activity concentrations $\left(\mathrm{Bq} \mathrm{kg}^{-1}\right)$} & \multirow{2}{*}{$\begin{array}{c}D \\
\left(\text { nGy h }^{-1}\right)\end{array}$} & \multirow{2}{*}{$\begin{array}{c}\text { AEDE } \\
\left(\mathrm{mSv}^{-1}\right)\end{array}$} & \multirow{2}{*}{$\begin{array}{c}\mathrm{Ra}_{\mathrm{eq}} \\
\left(\mathrm{Bq} \mathrm{kg}^{-1}\right)\end{array}$} & \multirow{2}{*}{$H_{\mathrm{ex}}$} & \multirow{2}{*}{$I_{\gamma}$} \\
\hline & ${ }^{226} \mathrm{Ra}$ & ${ }^{232} \mathrm{Th}$ & ${ }^{40} \mathrm{~K}$ & & & & & \\
\hline \multicolumn{9}{|c|}{ Agricultural soil samples } \\
\hline S-A1 & $67.05 \pm 4.07$ & $121.56 \pm 8.35$ & $357.64 \pm 12.03$ & 118.76 & 0.145 & 394.7 & 0.724 & 0.9 \\
\hline S-A2 & $166.55 \pm 6.66$ & $180.45 \pm 3.15$ & $513.34 \pm 1.61$ & 207.34 & 0.254 & 819.86 & 1.252 & 1.62 \\
\hline S-A3 & $114.92 \pm 4.60$ & $150.61 \pm 2.44$ & $401.26 \pm 16.05$ & 160.79 & 0.197 & 669.26 & 0.974 & 1.26 \\
\hline S-A4 & $77.47 \pm 1.90$ & $95.83 \pm 1.18$ & $203.09 \pm 6.63$ & 102.14 & 0.125 & 275.05 & 0.621 & 0.8 \\
\hline S-A5 & $90.94 \pm 3.36$ & $112.29 \pm 1.8$ & $330.93 \pm 11.53$ & 123.63 & 0.151 & 506.33 & 0.746 & 0.97 \\
\hline S-A6 & $77.97 \pm 3.12$ & $95.55 \pm 1.96$ & $202.2 \pm 11.72$ & 102.16 & 0.125 & 274.75 & 0.621 & 0.8 \\
\hline S-A7 & $85.06 \pm 1.92$ & $134.92 \pm 2.02$ & $305.73 \pm 1.06$ & 133.53 & 0.163 & 378.48 & 0.814 & 1 \\
\hline S-A8 & $102.42 \pm 4.78$ & $155.71 \pm 2.6$ & $219.63 \pm 9.90$ & 150.52 & 0.184 & 338.5 & 0.923 & 1 \\
\hline S-A9 & $104.48 \pm 4.18$ & $167.6 \pm 0.4$ & $236.76 \pm 9.37$ & 159.36 & 0.195 & 358.85 & 0.978 & 1.26 \\
\hline S-A10 & $115.91 \pm 6.24$ & $135.91 \pm 2.74$ & $529.17 \pm 10.19$ & 157.702 & 0.193 & 717.72 & 0.947 & 1.24 \\
\hline S-A11 & $58.93 \pm 1.80$ & $87.98 \pm 1.35$ & $263.32 \pm 5.63$ & 91.34 & 0.112 & 299.5 & 0.552 & 0.7 \\
\hline S-A12 & $87.68 \pm 3.38$ & $98.08 \pm 3.24$ & $351.53 \pm 21.65$ & 114.4 & 0.140 & 370.53 & 0.688 & 0.8 \\
\hline S-A13 & $140.94 \pm 2.96$ & $174.13 \pm 2.63$ & $206.96 \pm 21.29$ & 178.9 & 0.219 & 375.165 & 1.096 & 1.3 \\
\hline S-A14 & $110.6 \pm 9.45$ & $143.31 \pm 8.89$ & $523.92 \pm 1.03$ & 159.5 & 0.195 & 718.95 & 0.959 & 1.24 \\
\hline S-A15 & $130.4 \pm 1.0$ & $155.5 \pm 1.1$ & $242.7 \pm 7.9$ & 164.28 & 0.201 & 384.14 & 1.003 & 1.28 \\
\hline \multicolumn{9}{|c|}{ Virgin soil samples } \\
\hline S-V16 & $62.8 \pm 1.4$ & $75.2 \pm 1.5$ & $101.3 \pm 13.5$ & 78.65 & 0.096 & 173.13 & 0.481 & 0.6 \\
\hline S-V17 & $75.2 \pm 1.4$ & $80.4 \pm 1.3$ & $158.3 \pm 15.3$ & 89.90 & 0.110 & 231.66 & 0.545 & 0.7 \\
\hline S-V18 & $72.7 \pm 1.6$ & $104.7 \pm 2.1$ & $156.5 \pm 9.0$ & 103.34 & 0.126 & 283.22 & 0.631 & 0.6 \\
\hline S-V19 & $65.3 \pm 1.4$ & $67.3 \pm 1.4$ & $197.5 \pm 13.4$ & 79.05 & 0.096 & 246.3 & 0.477 & 0.6 \\
\hline S-V20 & $56.6 \pm 1.2$ & $77.7 \pm 1.3$ & $99.2 \pm 12.1$ & 78.06 & 0.095 & 166.4 & 0.473 & 0.6 \\
\hline S-V21 & $111.4 \pm 1.3$ & $120.2 \pm 1.4$ & $119.5 \pm 14.0$ & 129.04 & 0.158 & 255.09 & 0.789 & 1 \\
\hline S-V22 & $87.59 \pm 3.90$ & $94.2 \pm 2.07$ & $126.62 \pm 8.64$ & 120.63 & 0.147 & 225.6 & 0.626 & 0.6 \\
\hline S-V23 & $57.8 \pm 1.3$ & $63.2 \pm 1.3$ & $172.2 \pm 9.6$ & 72.05 & 0.088 & 217.57 & 0.434 & 0.5 \\
\hline S-V24 & $60.73 \pm 2.43$ & $70.71 \pm 1.24$ & $144.8 \pm 5.45$ & 76.80 & 0.094 & 273.34 & 0.467 & 0.6 \\
\hline S-V25 & $61.4 \pm 1.4$ & $65.3 \pm 1.3$ & $103.9 \pm 7.5$ & 72.13 & 0.088 & 169.48 & 0.438 & 0.5 \\
\hline S-V26 & $72.74 \pm 5.13$ & $127.35 \pm 6.03$ & $172.85 \pm 7.71$ & 117.72 & 0.144 & 260.6 & 0.722 & 0.7 \\
\hline S-V27 & $47.37 \pm 1.9$ & $51.83 \pm 1.18$ & $163.09 \pm 6.63$ & 59.98 & 0.073 & 195.23 & 0.362 & 0.4 \\
\hline S-V28 & $48.6 \pm 1.92$ & $105.73 \pm 1.06$ & $145.73 \pm 1.06$ & 92.38 & 0.113 & 206.27 & 0.569 & 0.5 \\
\hline S-V29 & $53.3 \pm 1.2$ & $88.2 \pm 9.4$ & $90.2 \pm 9.4$ & 81.65 & 0.100 & 160.68 & 0.502 & 0.6 \\
\hline S-V30 & $45.11 \pm 2.44$ & $58.91 \pm 1.61$ & $103.11 \pm 13.16$ & 60.71 & 0.074 & 149.83 & 0.370 & 0.4 \\
\hline
\end{tabular}

of ${ }^{238} \mathrm{U},{ }^{226} \mathrm{Ra},{ }^{232} \mathrm{Th}$, and ${ }^{226} \mathrm{Ra}$ decay products; this phenomenon results in the high activity of ${ }^{40} \mathrm{~K}$ in soil [30].

High radioactivity concentrations in the soil of the present studied area were also reported in previous studies by Ahmad et al. [7, 31] but were lower than those of ${ }^{226} \mathrm{Ra}$, ${ }^{232} \mathrm{Th}$, and ${ }^{40} \mathrm{~K}$ reported by Almayahi et al. [5] and Ahmad et al. [7, 31], as well as by Saleh et al. [6] in virgin soil samples.

The mean radioactivity concentrations of ${ }^{232}$ Th and ${ }^{226} \mathrm{Ra}$ in virgin soil in the present study are higher than those reported by UNSCEAR [2] (Table 7), whereas the mean value of ${ }^{40} \mathrm{~K}$ is slightly lower than that reported worldwide, except for Japan and Egypt.

Variations in the radioactivity concentrations in soils of various locations worldwide depend on the geographical and geological conditions of the zone and the extent of fertilizer utilized in farmland $[32,33]$.

\subsection{Radiological Hazard Assessment}

3.2.1. Assessment of Radium Equivalent $\left(R a_{e q}\right)$. Gamma-ray radiation hazards caused by specific radionuclides of ${ }^{226} \mathrm{Ra}$,
${ }^{232} \mathrm{Th}$, and ${ }^{40} \mathrm{~K}$ were evaluated using different indices. $\mathrm{Ra}$ eq, which is the radium equivalent activity, is the most widely used radiation hazard index $[34,35] . \mathrm{Ra}_{\mathrm{eq}}$ is the weighted sum of activities of the three radionuclides based on the supposition that $370 \mathrm{~Bq} \mathrm{~kg}^{-1}{ }^{226} \mathrm{Ra}, 259 \mathrm{~Bq} \mathrm{~kg}^{-1}{ }^{232} \mathrm{Th}$, and $481 \mathrm{~Bq} \mathrm{~kg}{ }^{-1}{ }^{40} \mathrm{~K}$ produce the same gamma-ray dose rate [36]. $\mathrm{Ra}_{\mathrm{eq}}$ is given by [37]

$$
\mathrm{Ra}_{\text {eq }}\left(\mathrm{Bq} \mathrm{kg}^{-1}\right)=\mathrm{CRa}+1.43 C \mathrm{Th}+0.077 C \mathrm{~K},
$$

where $C R a, C T h$, and $C K$ are the activity concentrations of ${ }^{226} \mathrm{Ra},{ }^{232} \mathrm{Th}$, and ${ }^{40} \mathrm{~K}$ (in $\mathrm{Bq} \mathrm{kg}^{-1}$ ), respectively.

To keep the annual radiation dose below $1.5 \mathrm{~m} \mathrm{~Gy}^{-1}$, the maximum value must be less than $370 \mathrm{~Bq} \mathrm{~kg}^{-1}$ [8].

As shown in Table $5, \mathrm{Ra}_{\text {eq }}$ of agricultural soil samples was within the range of $274.75-819.86 \mathrm{~Bq} \mathrm{~kg}^{-1}$, with a mean value of $458.785 \mathrm{~Bq} \mathrm{~kg}^{-1}$, which exceeds the permissible limit $\left(370 \mathrm{~Bq} \mathrm{~kg}^{-1}\right)$ recommended by the Organization for Economic Cooperation and Development [38]. The mean of $\mathrm{Ra}_{\mathrm{eq}}$ in the virgin soil was found to be $214.293 \mathrm{~Bq} \mathrm{~kg}^{-1}$, which is within the permissible limit. 
TABLE 3: The mean activity concentrations of natural radioactivity of agriculture and virgin soils in the present study were compared with those from similar investigations performed in other countries.

\begin{tabular}{|c|c|c|c|c|c|c|c|}
\hline \multirow{3}{*}{ Region/country } & \multicolumn{6}{|c|}{ Concentration in soil $\left(\mathrm{Bq} \mathrm{kg}^{-1}\right)$} & \multirow{3}{*}{ Reference } \\
\hline & \multicolumn{2}{|c|}{${ }^{226} \mathrm{Ra}$} & \multicolumn{2}{|c|}{${ }^{232} \mathrm{Th}$} & \multicolumn{2}{|c|}{${ }^{40} \mathrm{~K}$} & \\
\hline & Mean & Range & Mean & Range & Mean & Range & \\
\hline \multicolumn{8}{|c|}{ Virgin soil } \\
\hline Malaysia (Penang) & 396 & & 165 & & 835 & & Almayahi et al. [5] \\
\hline Malaysia (Pontian) & 37 & & 53 & & 293 & & Saleh et al. [6] \\
\hline Malaysia (Kedah) & 51.06 & & 78.44 & & 125.66 & & Ahmad et al. [7] \\
\hline Malaysia & 65.24 & $45.11-111.4$ & 83.39 & $51.83-127.35$ & 136.98 & $99.2-172.8$ & The present study \\
\hline \multicolumn{8}{|c|}{ Agriculture soil } \\
\hline Malaysia (Kedah) & 80.63 & & 116.87 & & 200.66 & & Ahmad et al. [7] \\
\hline India & 64 & & 93 & & 124 & & Singh et al. [8] \\
\hline Pakistan & 30 & & 56 & & 602 & & Tufail et al. [9] \\
\hline Algeria & 53.2 & & 50.03 & & 311 & & Boukhenfouf and Boucenna [10] \\
\hline Egypt & 43 & $5.7-140$ & 54 & $9-139$ & 183 & $22-319$ & Issa [11] \\
\hline Thailand & 43 & $11-78$ & 51 & $7-120$ & 230 & $7-712$ & UNSCEAR [2] \\
\hline Malaysia & 66 & $49-86$ & 82 & $63-110$ & 310 & $170-430$ & UNSCEAR [2] \\
\hline Greece & $16 \pm 6$ & $12-26$ & $55 \pm 14$ & $39-72$ & $305 \pm 59$ & $222-376$ & Ioannides et al. [12] \\
\hline Malaysia & $102.08 \pm 3.96$ & $58.93-166.55$ & 133.96 & $87.98-180.45$ & 325.87 & $202.2-529.17$ & The present study \\
\hline
\end{tabular}

The permissible limit of $\mathrm{Ra}_{\mathrm{eq}}$ in building materials must be $<370 \mathrm{~Bq} \mathrm{~kg}^{-1}$, which is equal to an annual dose of $1.5 \mathrm{mSv} \mathrm{y}^{-1}[39,40]$.

3.2.2. Absorbed Dose Rate in Air (D). According to the guidelines provided by UNSCEAR [2], the absorbed gamma dose rate $D_{R}\left(n G y h^{-1}\right)$ in air was determined at $1 \mathrm{~m}$ above the ground surface to ensure uniform distribution of radionuclides. This parameter can be used to assess any radiological hazard and radiation exposure from radionuclides in the soil; the absorbed dose rate was calculated using the following formula [41]:

$$
D_{R}\left(\mathrm{nG} \mathrm{h}^{-1}\right)=0.427 C \mathrm{Ra}+0.623 C \mathrm{Th}+0.043 C \mathrm{~K},
$$

where $D_{R}$ is the dose rate in $\mathrm{nGy} \mathrm{h}^{-1}$ and $C \mathrm{Ra}, C \mathrm{Th}$, and $C \mathrm{~K}$ are the activity concentrations $\left(\mathrm{Bq} \mathrm{kg}^{-1}\right)$ of radium $\left({ }^{226} \mathrm{Ra}\right)$, thorium $\left({ }^{232} \mathrm{Th}\right)$, and potassium $\left({ }^{40} \mathrm{~K}\right)$, respectively.

The absorbed dose rate indicates the received dose outdoors from radiation emitted by radionuclides in environmental materials. Determination of this rate is the main step for evaluating health risk, and this parameter is expressed in gray.

Table 5 shows the absorbed dose rate calculated from the radioactivity concentrations of ${ }^{226} \mathrm{Ra},{ }^{232} \mathrm{Th}$, and ${ }^{40} \mathrm{~K}$ in agricultural and virgin soil samples.

The absorbed dose rate in agricultural soil ranged from $91.34 \mathrm{nGyh}^{-1}$ to $207.34 \mathrm{nGyh}^{-1}$, with a mean value of $141.62 \mathrm{nGy} \mathrm{h}^{-1}$, which is higher than the global mean value of $60 \mathrm{nGy} \mathrm{h}^{-1}$ established by UNSCEAR [2].

The average value of the absorbed dose rate $D\left(\mathrm{nGy} \mathrm{h}^{-1}\right)$ of agricultural soils in the present study is higher than those reported in other countries (Table 6). The absorbed gamma dose rate in virgin soil samples ranged from $60.71 \mathrm{nGy} \mathrm{h}^{-1}$ to $129.04 \mathrm{nGy} \mathrm{h}^{-1}$, with an average value of $87.47 \mathrm{nGy} \mathrm{h}^{-1}$, which is higher than the mean values reported in United States, Japan, Egypt, Poland, and Switzerland (Table 7) and the value recommended by UNSCEAR [2].

3.2.3. The Annual Effective Dose Rate. Annual effective dose should be calculated to assess the health effects of the absorbed dose by using a conversion coefficient $\left(0.7 \mathrm{~Sv} \mathrm{~Gy}^{-1}\right)$ to transform absorbed dose in air to the effective dose received by humans, with an outdoor occupancy factor $(0.2)$, which is equivalent to an outdoor occupancy of $20 \%$ and $80 \%$ for the indoors $[38,42]$. This factor is suitable for determining the pattern of life in the studied area. Annual effective dose rate $\left(\mathrm{AEDR}\right.$, in $\mathrm{mSv}^{-1}$ ) received by the population can be calculated using $[43,44]$

$$
\begin{aligned}
& \text { Annual effective dose rate }\left(\mathrm{mSv} \mathrm{y}^{-1}\right) \\
& \begin{array}{l}
=\text { Absorbed dose }\left(\mathrm{nGy}^{-1}\right) \times 8760 \mathrm{~h} \cdot \mathrm{yr}^{-1} \times 0.7 \\
\quad \times\left(10^{3} \mathrm{mSv} / 10^{-9}\right) \times 0.2\left(\mathrm{nGy}^{-1}\right) \\
=D \times 1.2264 \times 10^{-3}\left(\mathrm{mSv} \mathrm{y}^{-1}\right),
\end{array}
\end{aligned}
$$

where $D(\mathrm{nG} / \mathrm{h})$ is the total air absorbed dose rate in the outdoors; $8760 \mathrm{~h}$ is the number of hours in one year; 0.2 is the outdoor occupancy factor; $0.7 \mathrm{~Sv} \mathrm{~Gy}^{-1}$ is the conversion coefficient from absorbed dose in air to effective dose received by adults; $10^{-6}$ is the conversion factor between nano- and millimeasurements.

The estimated annual effective dose in the agricultural soil samples ranged from $0.112 \mathrm{mSv} \mathrm{y}^{-1}$ to $0.254 \mathrm{mSv} \mathrm{y}^{-1}$, with 
TABLE 4: Gamma-index $\left(I_{\gamma}\right)$ values proposed by the European Commission (1999) taking in to account typical way and amounts in which the material is used in a building [13].

\begin{tabular}{lcc}
\hline Dose criterion & $0.3 \mathrm{mSv} \mathrm{y}^{-1}$ & $1 \mathrm{mSv} \mathrm{y}^{-1}$ \\
\hline Materials used in bulk amounts & $I_{\gamma} \leq 0.5$ & $I_{\gamma} \leq 1$ \\
$\begin{array}{l}\text { For example, bricks superficial and other materials } \\
\text { with restricted use: tiles, boards, and so forth }\end{array}$ & $I_{\gamma} \leq 2$ & $I_{\gamma} \leq 6$ \\
\hline
\end{tabular}

an average value of $0.169 \mathrm{mSvy}^{-1}$, whereas that for virgin soil samples ranged from $0.073 \mathrm{mSv}^{-1}$ to $0.158 \mathrm{mSv} \mathrm{y}^{-1}$, with an average value of $0.106 \mathrm{mSvy}^{-1}$. As shown in (Table 5), the worldwide average annual effective dose is approximately $0.5 \mathrm{mSv}^{-1}$ [2]. Thus, the present average annual effective dose rates are within the average values reported worldwide.

Indoor dose rates were not evaluated because data on average buildup of radon gas in the indoor atmosphere were not available.

3.2.4. External Hazard Index $\left(H_{e x}\right)$. The external hazard index for samples under investigation was calculated using the equation defined by [33].

$$
H_{\mathrm{ex}}=\frac{C \mathrm{Ra}}{370}+\frac{C \mathrm{Th}}{259}+\frac{C \mathrm{~K}}{4810} \leq 1,
$$

where $C R a, C T h$, and $C K$ are the activity concentrations of ${ }^{226} \mathrm{Ra}$, ${ }^{232} \mathrm{Th}$, and ${ }^{40} \mathrm{~K}$ in $\left(\mathrm{Bq} \mathrm{kg}^{-1}\right)$, respectively. The maximum value of $H_{\mathrm{ex}}$ equal to unity corresponds to the upper limit of $\mathrm{Ra}_{\mathrm{eq}}\left(370 \mathrm{~Bq} \mathrm{~kg}^{-1}\right)$.

The calculated values of $H_{\mathrm{ex}}$ for agricultural soil samples ranged from 0.552 to 1.252 , with a mean value 0.859 , whereas those for virgin soil samples ranged from 0.362 to 0.789 , with an average value 0.525 (Table 5). The value of $H_{\mathrm{ex}}$ must be lower than unity to keep the radiation hazard insignificant. These values are less than the limit $\left(H_{\mathrm{ex}}\right.$ less than or equal to one) established by the European Commission on Radiation Protection (1999) [13]; hence, terrestrial soils from the study area present low radiation exposure for people and can be used as a construction material without posing any significant radiological threat to the general population.

3.2.5. Gamma Index $\left(I_{\gamma}\right)$. Gamma index $\left(I_{\gamma}\right)$ proposed by the European Commission has been calculated from the activity concentrations of ${ }^{226} \mathrm{Ra},{ }^{232} \mathrm{Th}$, and ${ }^{40} \mathrm{~K}$ in soil samples using the following formula [13]:

$$
I_{\gamma}=\frac{A_{\mathrm{Ra}}}{300}+\frac{A_{\mathrm{Th}}}{200}+\frac{A_{\mathrm{K}}}{3000} \leq 1,
$$

where $A_{\mathrm{Ra}}, A_{\mathrm{Th}}$, and $A_{\mathrm{K}}$ are the activity concentrations $\left(\mathrm{Bq} \mathrm{kg}^{-1}\right)$ of radium $\left({ }^{226} \mathrm{Ra}\right)$, thorium $\left({ }^{232} \mathrm{Th}\right)$, and potassium $\left({ }^{40} \mathrm{~K}\right)$, respectively.

Values of index $I_{\gamma} \leq 2$ correspond to an absorbed gamma dose rate of $0.3 \mathrm{mSv} /$ year, whereas $2<\gamma \leq 6$ corresponds to an absorbed gamma dose rate of $1 \mathrm{mSv} /$ year $[13,45]$, andmaterials with $I_{\gamma}>6$ correspond to dose rates higher than $1 \mathrm{mSv} /$ year, which is the highest dose rate value recommended for the population [13].

Therefore, the annual effective dose that can be delivered by the soil as building materials in this study is lower than the annual effective dose constraint of $1 \mathrm{mSv} /$ year.

The calculated values of agricultural and virgin soil samples are presented in Tables 2 and 5; gamma indices of agricultural soil are varying from 0.7 to 1.6 , with a mean value of one that is found to be higher than the limit of 0.5 , while those found in the virgin soils are varying from 0.4 to 1 with a mean value of 0.59 . It is observed that the mean values of agricultural and virgin soils did not exceed the recommended upper limit (Table 4). Therefore, the annual effective dose that can be delivered by the soil as building materials in this study is lower than the annual effective dose constraint of $1 \mathrm{mSv} /$ year.

Moreover, the gamma-index values of our study are comparable with results of various studies around the world (Table 6).

\section{Conclusion}

Gamma spectrometry was used to measure the radioactivity concentration of 30 agricultural and virgin soil samples collected from Kedah Region, north of Malaysia. Results showed that the mean activity concentrations of ${ }^{226} \mathrm{Ra},{ }^{232} \mathrm{Th}$, and ${ }^{40} \mathrm{~K}$ are $102.08 \pm 3.96,133.96 \pm 2.92$, and $325.87 \pm 9.83 \mathrm{~Bq} \mathrm{~kg}^{-1}$, respectively, in agricultural soil samples and $65.24 \pm 2.00$, $83.39 \pm 2.27$, and $136.98 \pm 9.76 \mathrm{~Bq} \mathrm{~kg}^{-1}$ in virgin soil samples. The measured values are higher than those reported in other soils worldwide. The average activity concentrations of ${ }^{226} \mathrm{Ra}$ and ${ }^{232} \mathrm{Th}\left(\mathrm{Bq} \mathrm{kg}^{-1}\right)$ in virgin and agricultural soils are higher than the world recommended values UNSCEAR [2]. However, the average activity concentration of ${ }^{40} \mathrm{~K}$ is below the recommended values in both soil types. No ${ }^{137} \mathrm{Cs}$ activity concentration was found in any of the samples from this district, indicating the absence of artificial radionuclide fallout from any nuclear accidents.

The mean value of gamma absorbed dose in air outdoors are within the range of 91.34-207.34 $\mathrm{nGyh}^{-1}$, with a mean value of $141.62 \mathrm{nGy} \mathrm{h}^{-1}$, for agricultural soils and within 60.71-129.04 $\mathrm{nGyh}^{-1}$, with an average of $87.47 \mathrm{nGyh}^{-1}$, in virgin soil; these values are higher than the global average value of $60 \mathrm{nGyh}^{-1}$ UNSCEAR [2] in both soil types. 
TABLE 5: Range and mean value of activity concentrations of ${ }^{226} \mathrm{Ra},{ }^{232} \mathrm{Th}$, and ${ }^{40} \mathrm{~K}$ (in Bq kg ${ }^{-1}$ ), Ra equivalent $\mathrm{Ra}_{\mathrm{eq}}$ (Bq kg ${ }^{-1}$ ), absorbed dose rates $D\left(\mathrm{nGy} \mathrm{h}^{-1}\right)$, external hazard index $\left(H_{\mathrm{ex}}\right)$, annual effective dose rates, AEDE, $\left(\mathrm{mSv}^{-1}\right)$ in soil samples of Kedah.

\begin{tabular}{|c|c|c|c|c|}
\hline & Sample & Mean & Maximum & Minimum \\
\hline \multicolumn{5}{|l|}{ Radionuclides } \\
\hline \multirow{2}{*}{${ }^{226} \mathrm{Ra}$} & Agricultural soil & $102.08 \pm 3.96$ & $166.55 \pm 6.66$ & $58.93 \pm 1.80$ \\
\hline & Virgin soil & $65.24 \pm 2.00$ & $111.4 \pm 1.3$ & $45.11 \pm 2.44$ \\
\hline \multirow{2}{*}{${ }^{232} \mathrm{Th}$} & Agricultural soil & $133.96 \pm 2.92$ & $180.45 \pm 3.15$ & $87.98 \pm 1.35$ \\
\hline & Virgin soil & $83.39 \pm 2.27$ & $127.35 \pm 6.03$ & $51.83 \pm 1.18$ \\
\hline \multirow{2}{*}{${ }^{40} \mathrm{~K}$} & Agricultural soil & $325.87 \pm 9.83$ & $529.17 \pm 10.19$ & $202.2 \pm 11.72$ \\
\hline & Virgin soil & $136.98 \pm 9.76$ & $172.85 \pm 7.71$ & $99.2 \pm 12.1$ \\
\hline \multicolumn{5}{|l|}{ Radiological hazard } \\
\hline \multirow{2}{*}{$D\left(\mathrm{nGy} \mathrm{h}^{-1}\right)$} & Agricultural soil & 141.62 & 207.34 & 91.34 \\
\hline & Virgin soil & 87.47 & 129.04 & 60.71 \\
\hline \multirow{2}{*}{$\operatorname{AEDE}\left(\mathrm{mSv}^{-1}\right)$} & Agricultural soil & 0.169 & 0.254 & 0.112 \\
\hline & Virgin soil & 0.106 & 0.158 & 0.073 \\
\hline \multirow{2}{*}{$\mathrm{Ra}_{\mathrm{eq}}\left(\mathrm{Bq} \mathrm{kg}^{-1}\right)$} & Agricultural soil & 458.785 & 819.86 & 274.75 \\
\hline & Virgin soil & 214.293 & 283.22 & 149.83 \\
\hline \multirow{2}{*}{$H_{\mathrm{ex}}$} & Agricultural soil & 0.859 & 1.252 & 0.552 \\
\hline & Virgin soil & 0.525 & 0.789 & 0.362 \\
\hline \multirow{2}{*}{ Gamma index $I_{\gamma}$} & Agricultural soil & 1.07 & 1.62 & 0.7 \\
\hline & Virgin soil & 0.59 & 1 & 0.4 \\
\hline
\end{tabular}

TABLE 6: Average hazard indices of the primordial radionuclides in the worldwide agricultural soils.

\begin{tabular}{|c|c|c|c|c|c|}
\hline Location & $D(\mathrm{nGy} / \mathrm{h})$ & $D_{\text {eff }}(\mathrm{mSv} / \mathrm{y})$ & $H_{\mathrm{ex}}$ & $I_{\gamma}$ & Reference \\
\hline Vietnam & 71.72 & 0.54 & 0.43 & - & Huy et al. [14] \\
\hline India & 97.47 & 0.12 & & - & Mehra and Singh [15] \\
\hline Saudi Arabia & 23.3 & 0.14 & 0.13 & - & Alaamer [16] \\
\hline Malaysia & 202.04 & 0.23 & 1.19 & - & Musa et al. [17] \\
\hline Jordan & 51.50 & 0.06 & 0.28 & - & Al-Hamarneh and Awadallah [18] \\
\hline Pakistan & 68.83 & 0.34 & 0.39 & 0.14 & Rafique et al. [19] \\
\hline India & 90.1 & 0.11 & 0.53 & 0.71 & Zubair et al. [20] \\
\hline Egypt (Rashid) & 118.36 & 145.16 & 0.40 & 0.52 & EL-Kameesy et al. [21] \\
\hline India (Karnataka State) & 33.23 & 4.07 & 0.19 & 0.29 & Chandrashekara et al. [22] \\
\hline Malaysia & 141.62 & 0.169 & 0.859 & - & Present study \\
\hline Worldwide & 60 & 0.070 & 1 & - & UNSCEAR [2] \\
\hline
\end{tabular}

The average annual effective dosages from agricultural and virgin soil samples are also lower than the global average values.

The value of $\mathrm{Ra}_{\mathrm{eq}}$ activity concentrations for agricultural and virgin soil samples is less than $370 \mathrm{~Bq} \mathrm{~kg}^{-1}$, with the mean value exceeding the permissible limit recommended by the Organization for Economic Cooperation and Development (NEA-OECD report) [38] in agriculture soil samples.

The mean value of the external hazard index $H_{\mathrm{ex}}$ of the study area is found to be within the recommended safe levels $\left(H_{\mathrm{ex}}\right.$ less than or equal to one). The obtained results of gamma index $\left(I_{\gamma}\right)$ are within the recommended safety limits of European Commission (1999).
This study established a map of baseline information for future studies on radiation levels and radionuclide distribution in the environment of Kedah. The results of the study serve as a reference for future assessment.

\section{Competing Interests}

The authors declare that they have no competing interests.

\section{Acknowledgments}

This work is supported by University of Malaya by High Impact Research Grant H-21001-F0033 and Postgraduate Research Fund PG065-2013A. 
TABLE 7: Comparison of natural radioactivity levels measured in soil in the present study with the values reported in other countries worldwide and established by UNSCEAR [2].

\begin{tabular}{|c|c|c|c|c|c|c|c|c|}
\hline \multirow{3}{*}{ Region/country } & \multicolumn{6}{|c|}{ Concentration in soil $\left(\mathrm{Bq} \mathrm{kg}^{-1}\right)$} & \multirow{2}{*}{\multicolumn{2}{|c|}{$\begin{array}{c}\text { Absorbed dose rates } \\
\text { in air }\left(\mathrm{nGy} \mathrm{h}^{-1}\right)\end{array}$}} \\
\hline & \multicolumn{2}{|c|}{${ }^{226} \mathrm{Ra}$} & \multicolumn{2}{|c|}{${ }^{232} \mathrm{Th}$} & \multicolumn{2}{|c|}{${ }^{40} \mathrm{~K}$} & & \\
\hline & Mean & Range & Mean & Range & Mean & Range & Mean & Range \\
\hline Malaysia & 66 & $49-86$ & 82 & $63-110$ & 310 & $170-430$ & & \\
\hline United States & 40 & $8-160$ & 35 & $4-130$ & 370 & $100-700$ & 47 & $14-118$ \\
\hline Japan & 33 & $6-98$ & 28 & $2-88$ & 310 & $15-990$ & 53 & $35-70$ \\
\hline China & 32 & $2-440$ & 41 & $1-360$ & 440 & $9-1800$ & 62 & $2-340$ \\
\hline India & 29 & $7-81$ & 64 & $14-160$ & 400 & $38-760$ & 56 & $20-1100$ \\
\hline Egypt & 17 & $5-64$ & 18 & $2-96$ & 320 & $29-650$ & 32 & $20-133$ \\
\hline Iran & 28 & $8-55$ & 22 & $5-42$ & 640 & $250-980$ & 71 & $36-130$ \\
\hline Denmark & 17 & $9-29$ & 19 & $8-30$ & 460 & $240-610$ & 52 & $35-70$ \\
\hline Spain & 32 & $6-250$ & 33 & $2-210$ & 470 & $25-1650$ & 76 & $40-120$ \\
\hline Poland & 26 & $5-120$ & 21 & $4-77$ & 410 & $110-970$ & 45 & $18-97$ \\
\hline Switzerland & 40 & $10-900$ & 25 & $4-70$ & 370 & $40-1000$ & 45 & $15-120$ \\
\hline Portugal & 44 & $8-65$ & 51 & $22-100$ & 470 & $25-1650$ & 76 & $40-120$ \\
\hline Bulgaria & 45 & $12-210$ & 30 & $7-160$ & 400 & $40-800$ & 70 & $48-96$ \\
\hline Romania & 32 & $8-60$ & 38 & $11-75$ & 490 & $250-1100$ & 59 & $21-122$ \\
\hline Portugal & 44 & $8-65$ & 51 & $22-100$ & 470 & $25-1650$ & 76 & $40-120$ \\
\hline Present study & 65.24 & 45.11-111.4 & 83.39 & $51.83-127.35$ & 136.98 & $99.2-172.85$ & 141.62 & $91.34-207.34$ \\
\hline UNSCEAR, 2000 & 35 & & 30 & & 400 & & 60 & $53-98$ \\
\hline
\end{tabular}

\section{References}

[1] A. P. Radhakrishna, H. M. Somashekarappa, Y. Narayana, and K. Siddappa, "A new natural background radiation area on the southwest coast of india," Health Physics, vol. 65, no. 4, pp. 390395, 1993.

[2] United Nations Scientific Committee on the Effects of Atomic Radiation, "Sources and Effects of Ionizing Radiation," UNSCEAR 2000 Report Vol.1 to the General Assembly, with scientific annexes, United Nations Sales Publication, United Nations, New York, 2000.

[3] B. Skwarzec and L. Falkowski, "Accumulation of ${ }^{210}$ Po in Baltic invertebrates," Journal of Environmental Radioactivity, vol. 8, no. 2, pp. 99-109, 1988.

[4] J. Al-Jundi, B. A. Al-Bataina, Y. Abu-Rukah, and H. M. Shehadeh, "Natural radioactivity concentrations in soil samples along the Amman Aqaba Highway, Jordan," Radiation Measurements, vol. 36, no. 1-6, pp. 555-560, 2003.

[5] B. A. Almayahi, A. A. Tajuddin, and M. S. Jaafar, "Radiation hazard indices of soil and water samples in Northern Malaysian Peninsula," Applied Radiation and Isotopes, vol. 70, no. 11, pp. 2652-2660, 2012.

[6] M. A. Saleh, A. T. Ramli, Y. Alajerami, and A. S. Aliyu, "Assessment of natural radiation levels and associated dose rates from surface soils in Pontian district, Johor, Malaysia," Journal of Ovonic Research, vol. 9, no. 1, pp. 17-27, 2013.

[7] N. Ahmad, M. Jaafar, and M. Alsaffar, "Natural radioactivity in virgin and agricultural soil and its environmental implications in Sungai Petani, Kedah, Malaysia," Pollution, vol. 1, no. 3, pp. 305-313, 2015.

[8] S. Singh, A. Rani, and R. K. Mahajan, "226Ra, 232Th and $40 \mathrm{~K}$ analysis in soil samples from some areas of Punjab and
Himachal Pradesh, India using gamma ray spectrometry," Radiation Measurements, vol. 39, no. 4, pp. 431-439, 2005.

[9] M. Tufail, N. Akhtar, and M. Waqas, "Measurement of terrestrial radiation for assessment of gamma dose from cultivated and barren saline soils of Faisalabad in Pakistan," Radiation Measurements, vol. 41, no. 4, pp. 443-451, 2006.

[10] W. Boukhenfouf and A. Boucenna, "The radioactivity measurements in soils and fertilizers using gamma spectrometry technique," Journal of Environmental Radioactivity, vol. 102, no. 4, pp. 336-339, 2011.

[11] S. A. M. Issa, "Radiometric assessment of natural radioactivity levels of agricultural soil samples collected in Dakahlia, Egypt," Radiation Protection Dosimetry, vol. 156, no. 1, pp. 59-67, 2013.

[12] K. G. Ioannides, T. J. Mertzimekis, C. A. Papachristodoulou, and C. E. Tzialla, "Measurements of natural radioactivity in phosphate fertilizers," Science of the Total Environment, vol. 196, no. 1, pp. 63-67, 1997.

[13] European Commission Radiation Protection, "Radiological protection principles concerning the natural radioactivity of building materials," Brussels Report 112, European Commission, 1999.

[14] N. Q. Huy, P. D. Hien, T. V. Luyen et al., "Natural radioactivity and external dose assessment of surface soils in Vietnam," Radiation Protection Dosimetry, vol. 151, no. 3, pp. 522-531, 2012.

[15] R. Mehra and M. Singh, "Measurement of radioactivity of $238 \mathrm{U}$, $226 \mathrm{Ra}, 232 \mathrm{Th}$ and $40 \mathrm{~K}$ in soil of different geological origins in Northern India," Journal of Environmental Protection, vol. 2, no. 7, p. 960, 2011.

[16] A. S. Alaamer, "Assessment of human exposures to natural sources of radiation in soil of Riyadh, Saudi Arabia," Turkish 
Journal of Engineering and Environmental Sciences, vol. 32, no. 4, pp. 229-234, 2008.

[17] M. Musa, Z. Hamzah, and A. Saat, "Measurement of natural radionuclides in the soil of Highlands agricultural farmland," in Proceedings of the 3rd International Symposium and Exhibition in Sustainable Energy and Environment (ISESEE '11), pp. 172-176, IEEE, Melaka, Malaysia, June 2011.

[18] I. F. Al-Hamarneh and M. I. Awadallah, "Soil radioactivity levels and radiation hazard assessment in the highlands of northern Jordan," Radiation Measurements, vol. 44, no. 1, pp. 102-110, 2009.

[19] M. Rafique, H. Rehman, M. Matiullah et al., "Assessment of radiological hazards due to soil and building materials used in Mirpur Azad Kashmir; Pakistan," Iranian Journal of Radiation Research, vol. 9, no. 2, pp. 77-87, 2011.

[20] M. Zubair, D. Verma, A. Azam, and S. Roy, "Natural radioactivity and radiological hazard assessment of soil using gamma-ray spectrometry," Radiation Protection Dosimetry, vol. 155, no. 4, pp. 467-473, 2013.

[21] S. U. EL-Kameesy, S. A. EL-Fiki, M. S. Talaat et al., "Radioactivity levels and hazards of soil and sediment samples collected from Damietta and Rashid branches of the River Nile, Egypt," Global Journal of Physics, vol. 4, no. 1, 2016.

[22] M. S. Chandrashekara, K. M. Nagaraju, K. S. Pruthvi Rani, and L. Paramesh, "Natural radionuclide in soil samples and radiation dose to the population of Chamarajanagar district, Karnataka State, India," International Journal of Advanced Scientific and Technical Research, vol. 4, no. 4, pp. 466-474, 2014.

[23] A. El-Taher and S. Makhluf, "Natural radioactivity levels in phosphate fertilizer and its environmental implications in Assuit governorate, upper Egypt," Indian Journal of Pure and Applied Physics, vol. 48, no. 10, pp. 697-702, 2010.

[24] A. Guidebook, Measurement of Radionuclides in Food and the Environment, International Atomic Energy Agency IAEA, Vienna, Austria, 1989, http://www-pub.iaea.org/MTCD/Publications/ PDF/trs295_web.pdf.

[25] N. M. Ibrahiem, A. H. Abd El Ghani, S. M. Shawky, E. M. Ashraf, and M. A. Farouk, "Measurement of radioactivity levels in soil in the nile delta and middle egypt," Health Physics, vol. 64, no. 6, pp. 620-627, 1993.

[26] A. S. Mollah, M. M. Rahman, and M. A. Koddus, "Measurement of high natural background radiation levels by TLD at Cox's Bazar coastal areas in Bangladesh," Radiation Protection Dosimetry, vol. 18, no. 1, pp. 39-41, 1987.

[27] N. Akhtar, M. Tufail, M. Ashraf, and M. M. Iqbal, "Measurement of environmental radioactivity for estimation of radiation exposure from saline soil of Lahore, Pakistan," Radiation Measurements, vol. 39, no. 1, pp. 11-14, 2005.

[28] C. E. Pereira, V. K. Vaidyan, A. Sunil, S. Ben Byju, R. M. Jose, and P. J. Jojo, "Radiological assessment of cement and clay based building materials from southern coastal region of Kerala," Indian Journal of Pure \& Applied Physics, vol. 49, no. 6, pp. 372376, 2011.

[29] N. Ibrahim, "Natural activities of ${ }^{238} \mathrm{U},{ }^{232} \mathrm{Th}$ and ${ }^{40} \mathrm{~K}$ in building materials," Journal of Environmental Radioactivity, vol. 43, no. 3 , pp. 255-258, 1999.

[30] J. I. Skorovarov, V. V. Shatalov, V. I. Nikonov, and V. Y. Smironov, "Preservation of environment as basic principle in uranium ore processing technology".

[31] N. Ahmad, M. S. Jaafar, M. Bakhash, and M. Rahim, "An overview on measurements of natural radioactivity in
Malaysia," Journal of Radiation Research and Applied Sciences, vol. 8, no. 1, pp. 136-141, 2015.

[32] National Council on Radiation Protection and Measurements, "Natural Background Radiation in the United states," NCRP Report 45, National Council on Radiation Protection and Measurements, Bethesda, Md, USA, 1975.

[33] A. El-Taher, "INAA and DNAA for uranium determination in geological samples from Egypt," Applied Radiation and Isotopes, vol. 68, no. 6, pp. 1189-1192, 2010.

[34] J. Beretka and P. J. Mathew, "Natural radioactivity of australian building materials, industrial wastes and by-products," Health Physics, vol. 48, no. 1, pp. 87-95, 1985.

[35] R. Krieger, "Radioactivity of construction materials," Betonwerk und Fertigteil-Technik, vol. 47, no. 8, pp. 468-446, 1981.

[36] P. Kessaratikoon and S. Awaekechi, "Natural radioactivity measurement in soil samples collected from municipal area of Hat Yai district in Songkhla province, Thailand," KMITL Science and Technology Journal A, vol. 8, no. 2, pp. 52-58, 2008.

[37] E. R. L. I. N. G. Stranden, "Some aspects on radioactivity of building materials," Physica Norvegica, vol. 8, no. 3, pp. 163-167, 1976.

[38] OECD, "Exposure to radiation from the natural radioactivity in building materials," Report by a Group of Experts of the OECD, Nuclear Energy Agency, Paris, France, 1979.

[39] UNSCEAR, Ionizing Radiation Sources and Biological Effects, United Nations Scientific Committee on the Effects of Atomic Radiation, Report to General Assembly, with Annexes, United Nations, New York, NY, USA, 1982.

[40] Organization for Economic Cooperation and Development, Exposure to radiation from the natural radioactivity in building materials (OECD, Paris), Report by a Group of Experts of the OECD, Nuclear Energy Agency, 1979.

[41] R. Veiga, N. Sanches, R. M. Anjos et al., "Measurement of natural radioactivity in Brazilian beach sands," Radiation Measurements, vol. 41, no. 2, pp. 189-196, 2006.

[42] United Nations Scientific Committee on the Effects of Atomic Radiation (UNSCEAR), Ionizing Radiation: Sources and Effects of Ionizing Radiation, United Nations, New York, NY, USA, 1993.

[43] UNSCEAR, Source and Effects of Ionizing Radiation, Report to the General Assembly, United Nations, New York, NY, USA, 1988.

[44] U. Cevik, N. Damla, B. Koz, and S. Kaya, "Radiological characterization around the Afsin-Elbistan coal-fired power plant in Turkey," Energy \& Fuels, vol. 22, no. 1, pp. 428-432, 2008.

[45] EC (European Commission), Radiological Protection Principles Concerning the Natural Radioactivity of Building Materials; Radiation Protection 112 [Ph.D. thesis], General Environment, Nuclear Safety and Civil Protection, Luxembourg, Belgium, 2000. 


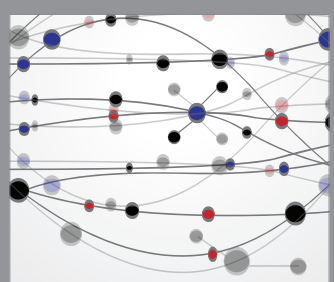

The Scientific World Journal
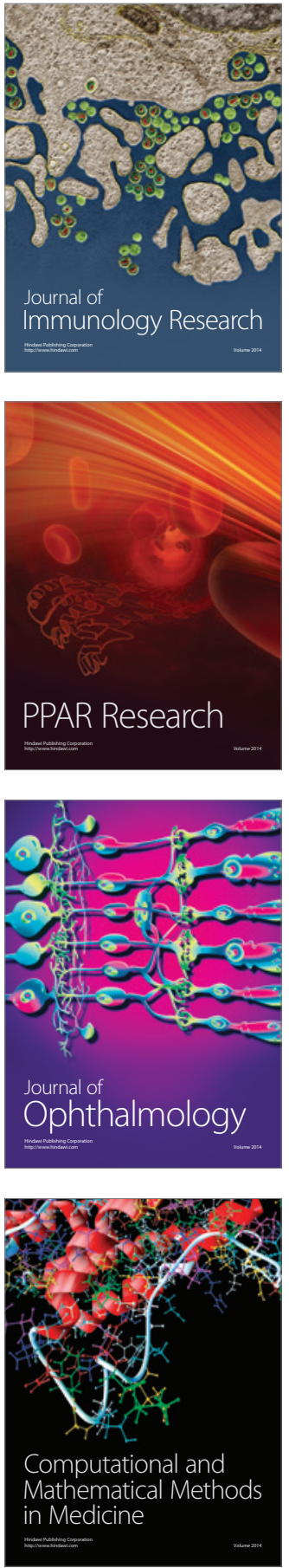

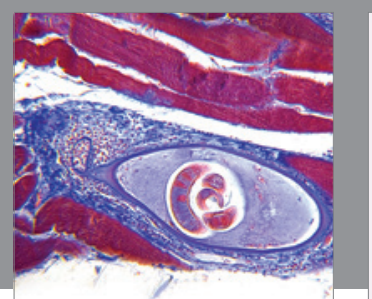

Gastroenterology Research and Practice

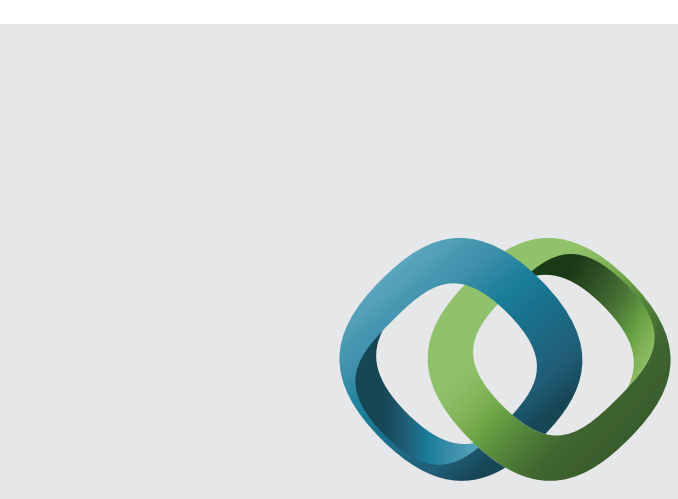

\section{Hindawi}

Submit your manuscripts at

http://www.hindawi.com
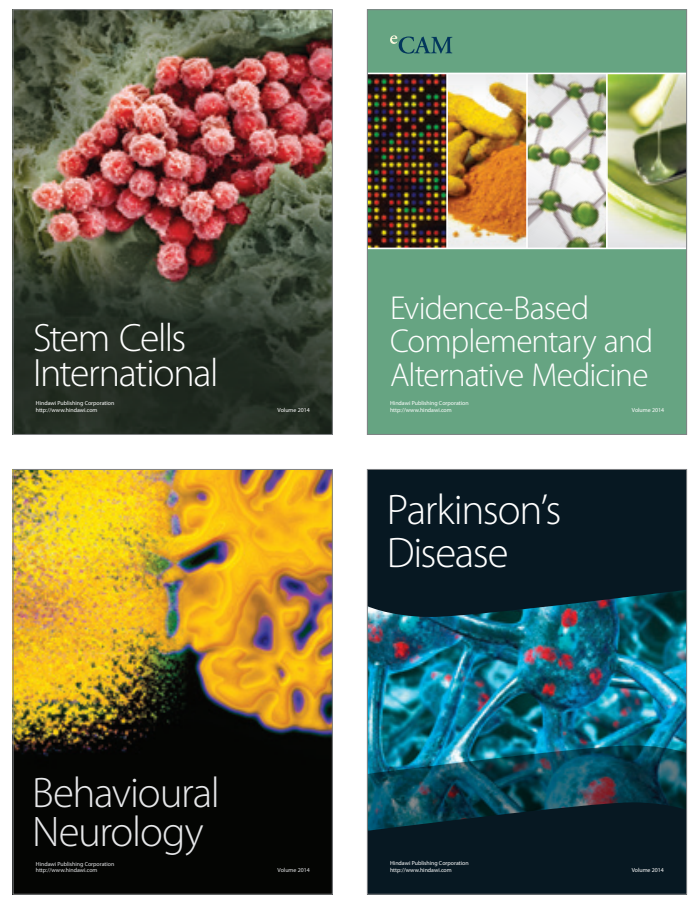
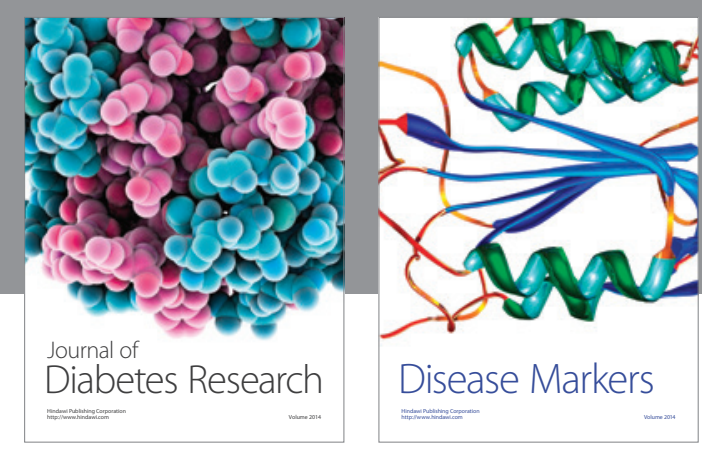

Disease Markers
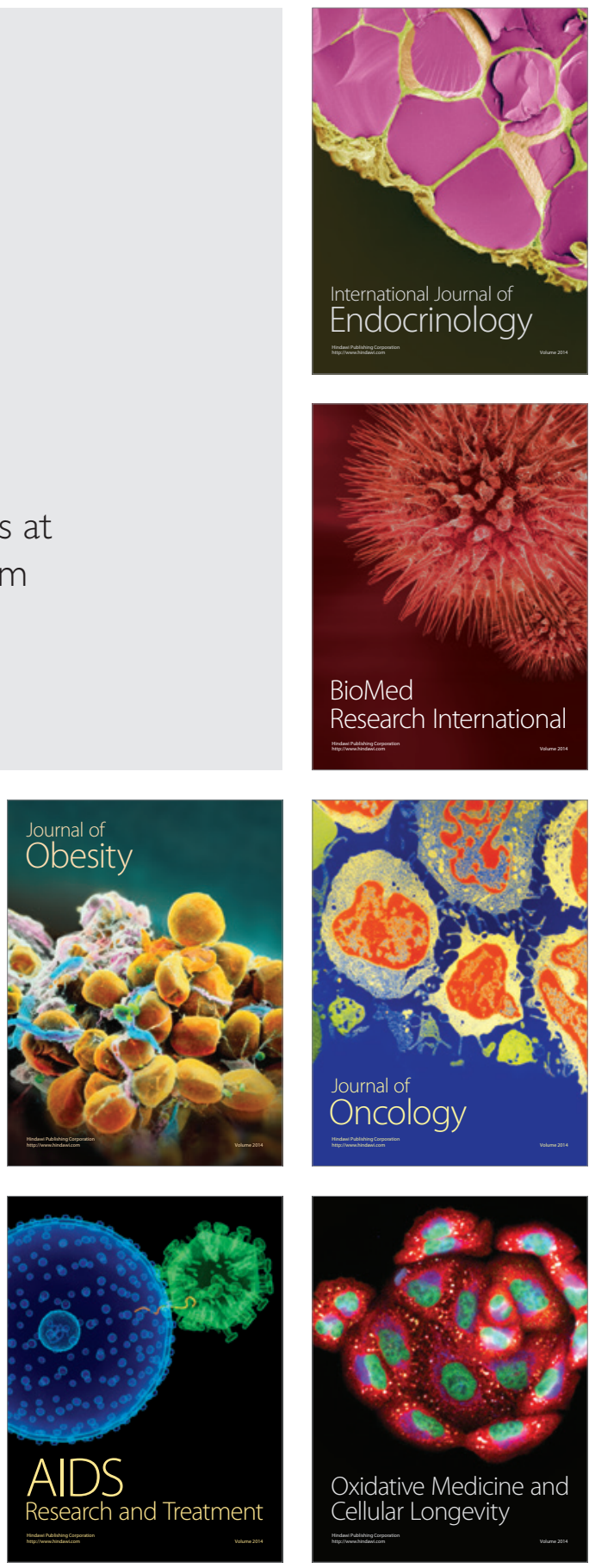